\title{
PERSISTENT HIGH POSTOPERATIVE CARCINOEMBRYONIC ANTIGEN IN COLORECTAL CANCER PATIENTS- IS IT IMPORTANT?
}

\author{
Ali Ilker Filiz, Ilker Sucullu, Yavuz Kurt, Dursun Ozgur Karakas, Bulent \\ Gulec, Mehmet Levhi Akin
}

doi: $10.1590 / \mathbf{S 1 8 0 7 - 5 9 3 2 2 0 0 9 0 0 0 4 0 0 0 0 4}$

Filiz AI, Sucullu I, Kurt Y, Karakas DO, Gulec B, Akin ML. Persistent high postoperative carcinoembryonic antigen in colorectal cancer patients- is it important? Clinics. 2009;64(4):287-94

INTRODUCTION: Evaluation of pre- and postoperative serum CEA levels together has seldom been assessed for the prognosis of colorectal cancer (CRC).

OBJECTIVE: To concurrently evaluate pre- and postoperative CEA as factors of relapse and survival.

METHODS: The study consisted of 114 patients who had undergone surgery from February 2002 to June 2006 for CRC. All patients were classified into four groups according to their pre- and postoperative CEA levels. Data obtained for clinicopathologic parameters, lymph node metastasis, stage, recurrence, and CEA levels were analyzed to determine their association with survival. Multivariate analysis by the Cox proportional hazard regression model was performed to identify the independent prognostic factors associated with survival.

RESULTS: Postoperative serum CEA levels remained high in Group $3(\mathrm{n}=32)$. Nineteen patients $(59.3 \%)$ demonstrated a detectable cause for persistent high CEA levels, while the reasons for those in the other thirteen patients (40.6\%) remained obscure. Abnormal preoperative CEA levels significantly correlated with the depth of tumor invasion, lymph node metastasis, TNM stage, and recurrence $(\mathrm{p}<0.05)$. Abnormal postoperative CEA levels were significantly related to the depth of tumor invasion, TNM stage, and postoperative relapse $(\mathrm{p}<0.05)$. Patients in Group 3 demonstrated the worst survival rate. Abnormal postoperative CEA levels, lymph node metastasis, and location of the tumor were independent prognostic factors for survival.

CONCLUSION: The survival of patients with high postoperative CEA levels due to unknown reasons may be extended if they are exhaustively tested with sensitive diagnostic methods and treated at an early stage.

KEYWORDS: Colorectal cancer; Carcinoembryonic antigen; Recurrence; Survival; Prognosis.

\section{INTRODUCTION}

Colorectal cancer (CRC) is a very serious health problem worldwide and is a leading cause of morbidity and mortality due to cancer. ${ }^{1}$ The best prognostic factor for these patients is tumor node metastasis (TNM) classification. ${ }^{2}$ However, there are some difficulties in obtaining the data preoperatively. Therefore, a search for preoperative prognostic parameters may be important for assessing the outcome of CRC patients.

Gulhane Military Medical Academy, Haydarpasa Training Hospital, Department of General Surgery - Istanbul, Turkey.

Email: dralifiliz@yahoo.com

Phone: 902165422020

Received for publication on August 26, 2008

Accepted for publication on December 17, 2008
Carcinoembryonic antigen (CEA) is the most commonly studied tumor marker in CRCs. ${ }^{3}$ The clinical significance of CEA in CRC patients has been well investigated, and elevated preoperative serum CEA levels have been associated with advanced tumor stage ${ }^{4-7}$ The prognostic significance of postoperative serum CEA levels or the evaluation of both pre- and postoperative serum CEA levels have seldom been discussed. The importance of this tumor marker in relapse and survival of CRC patients has rarely been explored. The aim of this retrospective study was to evaluate the value of pre-and postoperative CEA concurrently as a significant factor in the relapse and survival of CRC patients.

\section{MATERIALS AND METHODS}

The medical records of 151 patients with colorectal 
carcinoma that were admitted to our department from February 2002 until June 2006 were reviewed. Of the 151 patients, 27 stage IV patients were excluded from the analysis. Patients who had undergone neoadjuvant chemotherapy and/or radiotherapy, patients with a known second neoplastic disease, and patients with clinically or pathologically confirmed abnormal liver function or liver cirrhosis were also excluded. An additional 10 patients were lost during follow-up. Finally, 114 patients who underwent curative surgical treatment for primary lesions and who had Stage I-III diseases were included in the study. Curative surgical treatment was defined as any gross residual tumor that did not remain in the surgical bed and a surgical resection margin that was pathologically negative for tumor invasion. Patients were staged according to the criteria of the American Joint Commission on Cancer (AJCC). ${ }^{8}$

All 114 patients were categorized into four groups according to pre- and postoperative CEA levels: Group 1 $(n=45)$ comprised patients with both pre- and postoperative serum CEA levels $<5 \mathrm{ng} / \mathrm{ml}$; Group $2(\mathrm{n}=22)$ comprised patients with preoperative serum CEA levels $<5 \mathrm{ng} / \mathrm{ml}$ and postoperative serum CEA levels $\geq 5 \mathrm{ng} / \mathrm{ml}$; Group 3 $(\mathrm{n}=32)$ included patients with both pre- and postoperative serum CEA levels $\geq 5 \mathrm{ng} / \mathrm{ml}$; Group $4(\mathrm{n}=15)$ consisted of patients with preoperative serum CEA levels $\geq 5 \mathrm{ng} / \mathrm{ml}$ and postoperative serum CEA levels $<5 \mathrm{ng} / \mathrm{ml}$.

Thirty-two patients presented high postoperative serum CEA levels. We divided these patients into two groups and analyzed each according to known and unknown causes of high serum CEA after surgery. The first group consisted of 13 patients $(40.6 \%)$ with an undetermined cause of high CEA, and the other 19 patients $(59.3 \%)$ had a known cause of high preoperative CEA. Additionally, patients with unknown causes were compared with those whose CEA levels decreased to within normal ranges $(<5 \mathrm{ng} / \mathrm{ml})$ after surgery.

\section{Detection of serum CEA}

Blood samples were obtained 1 week before and 4 weeks after surgery. Serum CEA levels were determined by an enzyme immunoassay test kit (DPC Diagnostic Product Co., Los Angeles, CA, USA) with the upper limit of normal defined as $5 \mathrm{ng} / \mathrm{ml}$ according to the manufacturer's instructions.

\section{Statistical Analyses}

All data were analyzed using the Statistical Package for the Social Sciences Version 13.0 software (SPSS Inc., Chicago, III., USA). The ${ }^{2}$ test was used to compare clinicopathologic parameters between groups and pre- and postoperative serum CEA levels. Multivariate analysis of independent prognostic factors for postoperative relapse was determined using logistic regression analysis. The cumulative survival rates were calculated by the KaplanMeier method, and differences in survival rates were analyzed by the log-rank test. A multivariate analysis of independent prognostic factors for survival was determined using the Cox proportional hazards model. A value of $\mathrm{p}<$ 0.05 was considered as statistically significant.

\section{RESULTS}

The patients had a median age of $73.5 \pm 12.08$ (range 24-92 years), and included $70(61.4 \%)$ men and 44 (38.6\%) women. The location of the primary lesion was the colon in $67(58.7 \%)$ patients, and the rectum in 47 (41.3\%). Twentyfour $(21.2 \%)$ patients were stage I, $49(42.9 \%)$ were stage II, and $41(35.9 \%)$ were stage III. Histologic tumor types were as follows: $15(13.1 \%)$ were well-differentiated, 88 (77.1\%) were moderately-differentiated, and 11 (9.8\%) were poorly-differentiated colorectal carcinomas. The follow-up was completed in March 2008, with a median follow-up period of 45 months (range 21 - 73 months). Forty-four patients $(38.5 \%)$ had a postoperative relapse due to either a local recurrence (8 patients / 18\%) or a distant metastasis (36 patients / 82\%). Among the 44 patients with postoperative relapse, $30(68.1 \%)$ died. Among the 36 patients with distant metastasis, 17 (47.2\%) were colon and 19 (52.8\%) were rectal cancers. The other 3 colon cancer and 5 rectal cancer patients demonstrated a local recurrence.

The characteristics of the CRC patients are summarized in Tables 1 and 2. Forty-seven patients (41.2\%) displayed abnormal preoperative serum CEA levels, and 54 (47.3\%) had abnormal postoperative serum CEA levels. Among the patients with abnormal preoperative serum CEA, the levels remained high for 32 (68\%) patients, despite surgical resection. Among the patients with normal preoperative serum CEA levels, 22 patients (22/67 32.8\%) exhibited abnormal postoperative serum CEA levels at the time of follow-up.

Preoperative serum CEA levels correlated significantly with the depth of tumor invasion $(\mathrm{p}=0.041)$, lymph node metastases $(p=0.022)$, TNM stage $(p=0.002)$, and postoperative relapse $(\mathrm{p}=0.018)$. Age, gender, tumor size, histologic type, and primary sites of the tumor (colon versus rectum) were not significant. Colorectal patients with abnormal postoperative serum CEA levels demonstrated a significant association with gender $(\mathrm{p}=0.02)$, depth of tumor invasion $(\mathrm{p}=0.015)$, advanced TNM stage $(\mathrm{p}=0.037)$, and recurrence $(\mathrm{p}=0.005)$. 
Table 1 - Characteristics of patients with low and high CEA levels

\begin{tabular}{|c|c|c|c|}
\hline & \multicolumn{2}{|c|}{ Preoperative CEA levels } & \multirow[b]{2}{*}{$\mathrm{p}$} \\
\hline & $\begin{array}{c}\geq 5 \mathrm{ng} / \mathrm{ml} \\
(\mathrm{n}=47)\end{array}$ & $\begin{array}{c}<5 \mathrm{ng} / \mathrm{ml} \\
(\mathrm{n}=67)\end{array}$ & \\
\hline \multicolumn{4}{|l|}{ Age } \\
\hline$<60$ years & 5 & 7 & 0.89 \\
\hline$\geq 60$ years & 42 & 60 & \\
\hline \multicolumn{4}{|l|}{ Gender } \\
\hline Male & 27 & 43 & 0.46 \\
\hline Female & 20 & 24 & \\
\hline \multicolumn{4}{|c|}{ Tumor size $(\mathrm{cm})$} \\
\hline$<5 \mathrm{~cm}$ & 20 & 38 & 0.16 \\
\hline$\geq 5 \mathrm{~cm}$ & 27 & 29 & \\
\hline \multicolumn{4}{|c|}{ Primary tumor location } \\
\hline Colon & 30 & 37 & 0.35 \\
\hline Rectum & 17 & 30 & \\
\hline \multicolumn{4}{|c|}{ Histologic differentiation } \\
\hline Well & 4 & 11 & 0.053 \\
\hline Moderate & 35 & 53 & \\
\hline Poor & 8 & 3 & \\
\hline \multicolumn{4}{|c|}{ Depth of tumor invasion } \\
\hline $\mathrm{T} 1$ & 2 & 4 & $0.017 *$ \\
\hline $\mathrm{T} 2$ & 2 & 18 & \\
\hline T3 & 40 & 41 & \\
\hline $\mathrm{T} 4$ & 3 & 4 & \\
\hline \multicolumn{4}{|c|}{ Lymph node metastases } \\
\hline No & 24 & 48 & $0.041 *$ \\
\hline N1 & 13 & 14 & \\
\hline $\mathrm{N} 2$ & 10 & 5 & \\
\hline \multicolumn{4}{|c|}{ TNM Staging system } \\
\hline I & 3 & 21 & $0.01 *$ \\
\hline II & 22 & 27 & \\
\hline III & 22 & 19 & \\
\hline \multicolumn{4}{|c|}{ Postoperative relapse } \\
\hline Absent & 18 & 25 & $0.018 *$ \\
\hline Present & 23 & 22 & \\
\hline
\end{tabular}

Among the 32 patients whose postoperative serum CEA levels remained high, the cause was unknown for 13 patients $(40.6 \%)$ and known for $19(59.3 \%)$ according to the findings of surgical exploration (Table 3). Statistical analysis demonstrated that clinicopathologic characteristics and overall survival rates were not significantly different between the two groups ( $p>0.05)$ (Figure 1). There was also no significant difference between patients with an unknown cause of high CEA levels $(n=13)$ and those whose levels
Table 2 - Demographic and clinical features, and postoperative CEA levels of patients with abnormal preoperative CEA levels

\begin{tabular}{|c|c|c|c|}
\hline & \multicolumn{2}{|c|}{ Postoperative CEA levels } & \multirow[b]{2}{*}{$\mathrm{P}$} \\
\hline & $\begin{array}{c}\geq 5 \mathrm{ng} / \mathrm{ml} \\
(\mathrm{n}=32)\end{array}$ & $\begin{array}{c}<5 \mathrm{ng} / \mathrm{ml} \\
(\mathrm{n}=15)\end{array}$ & \\
\hline \multicolumn{4}{|l|}{ Age } \\
\hline$<60$ years & 3 & 2 & 0,69 \\
\hline$\geq 60$ years & 29 & 13 & \\
\hline \multicolumn{4}{|l|}{ Gender } \\
\hline Male & 22 & 5 & $0,02^{*}$ \\
\hline Female & 10 & 10 & \\
\hline \multicolumn{4}{|c|}{ Tumor size $(\mathrm{cm})$} \\
\hline$<5 \mathrm{~cm}$ & 13 & 7 & 0,70 \\
\hline$\geq 5 \mathrm{~cm}$ & 19 & 8 & \\
\hline \multicolumn{4}{|c|}{ Primary tumor location } \\
\hline Colon & 20 & 10 & 0,78 \\
\hline Rectum & 12 & 5 & \\
\hline \multicolumn{4}{|c|}{ Histologic differentiation } \\
\hline Well & 2 & 2 & 0,15 \\
\hline Moderate & 23 & 12 & \\
\hline Poor & 7 & 1 & \\
\hline \multicolumn{4}{|c|}{ Depth of tumor invasion } \\
\hline $\mathrm{T} 1$ & 0 & 2 & $0,015^{*}$ \\
\hline $\mathrm{T} 2$ & 1 & 1 & \\
\hline $\mathrm{T} 3$ & 28 & 12 & \\
\hline $\mathrm{T} 4$ & 3 & 0 & \\
\hline \multicolumn{4}{|c|}{ Lymph node metastases } \\
\hline No & 15 & 9 & 0,23 \\
\hline N1 & 10 & 5 & \\
\hline N2 & 7 & 1 & \\
\hline \multicolumn{4}{|c|}{ TNM Staging system } \\
\hline I & 0 & 3 & $0,037 *$ \\
\hline II & 15 & 7 & \\
\hline III & 17 & 5 & \\
\hline \multicolumn{4}{|c|}{ Postoperative relapse } \\
\hline Absent & 8 & 10 & $0,005^{*}$ \\
\hline Present & 24 & 5 & \\
\hline
\end{tabular}

returned to normal values after surgery $(n=15)$. There was no significant association between demographics and clinical features $(p>0.05)$ (Table 4). However, the overall survival rate was significantly different $(\mathrm{p}=0.001)$, and patients with normal postoperative serum CEA levels demonstrated better survival than the patients whose serum CEA levels remains high because of unknown causes (Figure 2).

Postoperative serum CEA levels $(\mathrm{p}=0.02)$, lymph node metastases $(\mathrm{p}=0.0001)$, and primary tumor sites $(\mathrm{p}=0.01)$ were 
Table 3 - Demographic and clinical features and their causerelated association in patients with abnormal postoperative serum CEA levels

\begin{tabular}{ccc}
\hline High postoperative serum CEA levels $(\geq 5 \mathrm{ng} / \mathrm{ml})$ & \\
\hline $\begin{array}{c}\text { Unknown cause } \\
(\mathrm{n}=13)\end{array}$ & $\begin{array}{c}\text { Known cause } \\
(\mathrm{n}=19)\end{array}$ & $\mathrm{p}$ \\
\hline
\end{tabular}

\begin{tabular}{lccc}
\hline Age & & & \\
$<60$ years & 1 & 2 & 0,79 \\
$\geq 60$ years & 12 & 17 &
\end{tabular}

Gender

$$
\text { Male }
$$

$$
10
$$$$
12
$$

Female

$$
3
$$$$
7
$$

Tumor size $(\mathrm{cm})$

$$
<5 \mathrm{~cm}
$$$$
8
$$$$
8
$$$$
\geq 5 \mathrm{~cm}
$$$$
5
$$

Primary tumor location

$$
\text { Colon }
$$

Rectum

$$
7
$$$$
6
$$

Histologic differentiation

Well
Moderate
Poor

Depth of tumor invasion

$\mathrm{T} 1$
$\mathrm{~T} 2$
$\mathrm{~T} 3$
$\mathrm{~T} 4$

Lymph node metastases

$\begin{array}{lll}\text { N0 } & 5 & 10 \\ \text { N1 } & 3 & 7 \\ \text { N2 } & 5 & 2\end{array}$

TNM Staging system

\begin{tabular}{lccc} 
I & 0 & 0 & 0,44 \\
II & 5 & 10 & \\
III & 8 & 9 & \\
Postoperative relapse & & & 0,83 \\
Absent & 7 & 11 & \\
Present & 6 & 8 & \\
\hline
\end{tabular}

identified as independent prognostic factors for recurrence by multivariate logistic regression analysis (Table 5). Patients with abnormal postoperative serum CEA levels exhibited a relative risk of 4.050 for postoperative relapse compared to patients with normal postoperative serum CEA levels. In addition, lymph node metastases and primary tumor sites demonstrated a relative risk of 3.769 and 3.342 for recurrence, respectively. Abnormal postoperative serum CEA levels were

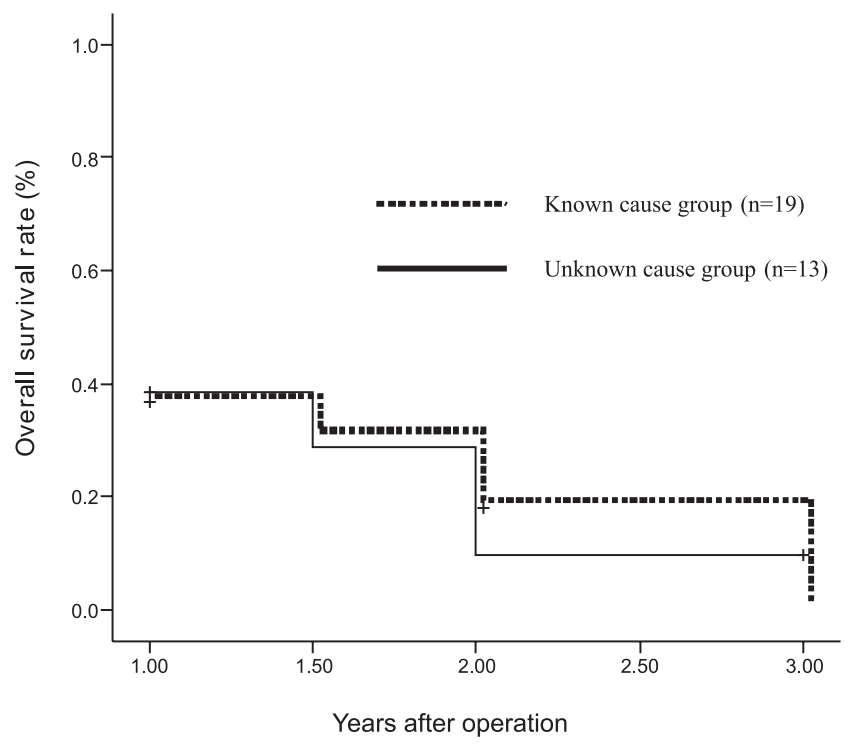

Figure 1 - Comparison of survival among patients with abnormal postoperative serum CEA levels

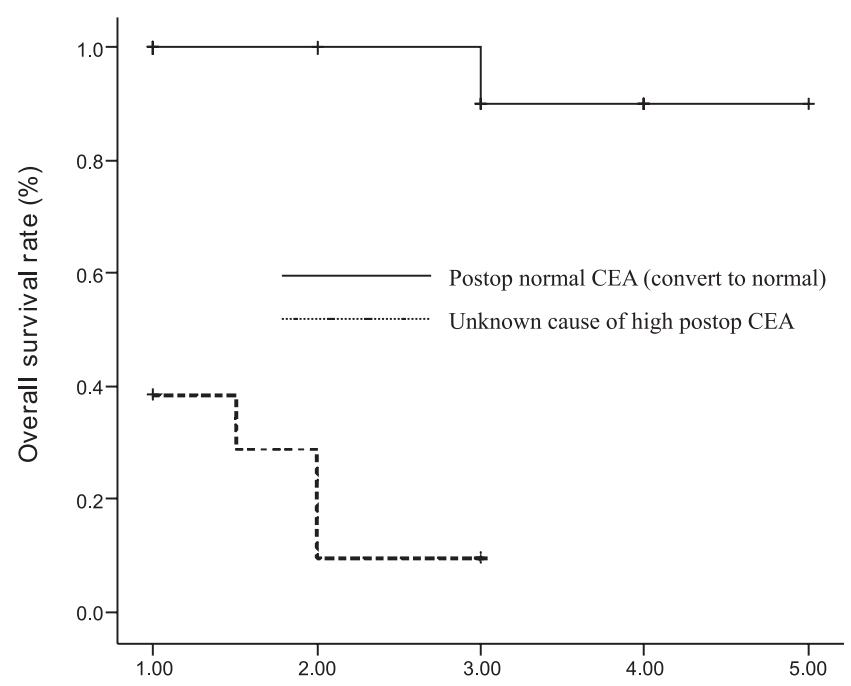

Figure 2 - Overall survival rates comparing patients whose serum CEA levels remained high for unknown reasons and those whose levels returned to normal after surgery

the only significant prognostic factor for survival according to Cox regression analysis $(\mathrm{p}=0.0001)$ (Table 6).

The overall survival rate for all groups is shown in Figure 3. Patients in groups 1 and 4 displayed significantly better survival rates than patients in groups 2 and $3(\mathrm{p}<0.0001)$. Patients in group three (both pre- and postoperative serum CEA levels $\geq 5 \mathrm{ng} / \mathrm{ml}$ ) demonstrated the worst survival rate among all groups $(\mathrm{p}<0.0001)$.

\section{DISCUSSION}

Carcinoembryonic antigen was first described in 1965 by 
Table 4 - Comparison of characteristics in patients with abnormal preoperative serum CEA levels

\begin{tabular}{|c|c|c|c|}
\hline & $\begin{array}{r}\text { Unknown cause } \\
\text { of postoperative } \\
\text { high CEA }(n=13)\end{array}$ & $\begin{array}{c}\text { Postoperative normal } \\
\text { CEA (convert to } \\
\text { normal) }(\mathrm{n}=15)\end{array}$ & $\mathrm{p}$ \\
\hline \multicolumn{4}{|l|}{ Age } \\
\hline$<60$ years & 1 & 2 & 0.64 \\
\hline$\geq 60$ years & 12 & 13 & \\
\hline \multicolumn{4}{|l|}{ Gender } \\
\hline Male & 10 & 5 & 0.02 \\
\hline Female & 3 & 10 & \\
\hline \multicolumn{4}{|c|}{ Tumor size (cm) } \\
\hline$<5 \mathrm{~cm}$ & 8 & 7 & 0.45 \\
\hline$\geq 5 \mathrm{~cm}$ & 5 & 8 & \\
\hline \multicolumn{4}{|l|}{$\begin{array}{l}\text { Primary tumor } \\
\text { location }\end{array}$} \\
\hline Colon & 7 & 10 & 0.51 \\
\hline Rectum & 6 & 5 & \\
\hline \multicolumn{4}{|c|}{$\begin{array}{l}\text { Histologic diffe- } \\
\text { rentiation }\end{array}$} \\
\hline Well & 0 & 2 & 0.17 \\
\hline Moderate & 11 & 12 & \\
\hline Poor & 2 & 1 & \\
\hline \multicolumn{4}{|l|}{$\begin{array}{l}\text { Depth of tumor } \\
\text { invasion }\end{array}$} \\
\hline $\mathrm{T} 1$ & 0 & 2 & 0.15 \\
\hline $\mathrm{T} 2$ & 1 & 1 & \\
\hline $\mathrm{T} 3$ & 11 & 12 & \\
\hline $\mathrm{T} 4$ & 1 & 0 & \\
\hline \multicolumn{4}{|l|}{$\begin{array}{l}\text { Lymph node } \\
\text { metastases }\end{array}$} \\
\hline No & 5 & 9 & 0.08 \\
\hline N1 & 3 & 5 & \\
\hline $\mathrm{N} 2$ & 5 & 1 & \\
\hline \multicolumn{4}{|l|}{$\begin{array}{l}\text { TNM Staging } \\
\text { system }\end{array}$} \\
\hline I & 0 & 3 & 0.05 \\
\hline II & 5 & 7 & \\
\hline III & 8 & 5 & \\
\hline \multicolumn{4}{|l|}{$\begin{array}{l}\text { Postoperative } \\
\text { relapse }\end{array}$} \\
\hline Absent & 7 & 5 & 0.29 \\
\hline Present & 6 & 10 & \\
\hline
\end{tabular}

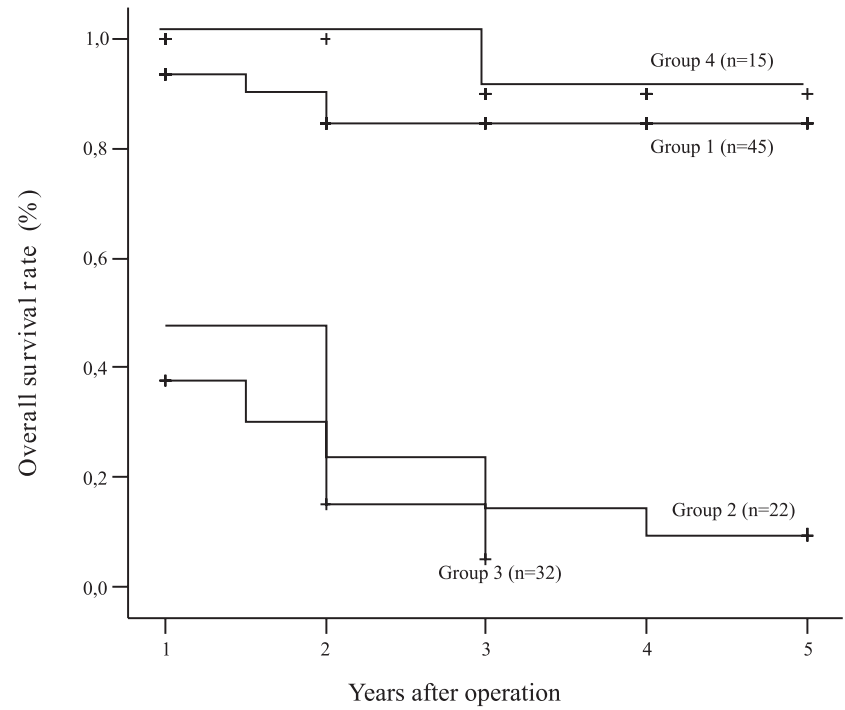

Figure 3 - Comparison of survival for groups 1-4

Gold and Freedman, and it has been the most investigated tumor marker in CRC patients ${ }^{1,9}$. Preoperative serum CEA levels have been widely used to evaluate tumor extension and outcome, and postoperative serum CEA levels have been correlated with recurrence. Many studies have shown that high preoperative levels are associated with poor prognosis. ${ }^{3,410,11}$ Similarly, some authors have reported that high postoperative CEA is an indicator of recurrence. ${ }^{12,13}$ However, the importance of abnormal preoperative serum CEA levels has rarely been investigated. In some patients, high preoperative CEA fails to return to normal levels after successful surgical resection. Therefore, the present study was performed to evaluate the correlation of preand postoperative serum CEA levels with recurrence and survival.

In many instances, the precise reasons for persistent high serum CEA levels cannot be determined. The possible causes for this failure include overlooked metastases or inadequate surgery ${ }^{2}$ However, smoking habits, renal insufficiency, or chronic pulmonary or liver diseases may also contribute to this condition..$^{1,2,21}$ In the present study, the cause of high serum CEA levels was unknown for almost $28 \%$ of the patients with persistent, high postoperative CEA levels. Although preoperative routine diagnostic methods

Table 5 - Multivariate analysis of factors releated to recurrence in CRC patients

\begin{tabular}{|c|c|c|c|c|c|c|}
\hline & \multirow{2}{*}{$\beta$} & \multirow{2}{*}{ SE } & \multirow{2}{*}{ OR } & \multirow{2}{*}{$\mathrm{P}$} & \multicolumn{2}{|c|}{$95 \% \mathrm{CI}$} \\
\hline & & & & & Lower & Upper \\
\hline Lymph node metastasis $(\mathrm{N} 1+\mathrm{N} 2 / \mathrm{N} 0)$ & 1.327 & 0.367 & 3,342 & 0.0001 & 1,836 & 7,738 \\
\hline Primary site of tumor (colon or rectum) & 1.207 & 0.466 & 3,769 & 0.01 & 1,342 & 8,325 \\
\hline Postoperative CEA levels ( $\geq 5 \mathrm{ng} / \mathrm{ml} /<5 \mathrm{ng} / \mathrm{ml}$ ) & 1.399 & 0.453 & 4,050 & 0.002 & 1,667 & 9,841 \\
\hline
\end{tabular}


Table 6 - Multivariate analysis of factors releated to survival in CRC patients

\begin{tabular}{lcccccc}
\hline & \multirow{2}{*}{ SE } & OR & P & \multicolumn{2}{c}{$95 \%$ CI } \\
\cline { 4 - 7 } & & & & Lower & Upper \\
\hline Postoperative CEA levels $(\geq 5 \mathrm{ng} / \mathrm{ml} /<5 \mathrm{ng} / \mathrm{ml})$ & -1.206 & 0.216 & 0.299 & 0.0001 & 0.196 & 0.457 \\
Preoperative CEA levels $(\geq 5 \mathrm{ng} / \mathrm{ml} /<5 \mathrm{ng} / \mathrm{ml})$ & -0.025 & 0.165 & 0.975 & 0.878 & 0.706 & 1.346 \\
\hline
\end{tabular}

(abdominal ultrasonography and abdominal computerized tomography) were used to detect metastases, intra-abdominal metastatic lesions were detected during surgery in 19 patients. We conclude that these lesions could explain the reason for the observed high CEA levels, but the failure of these levels to return to normal in patients with undetectable pre- or postoperative lesions remains unclear. Further investigation using techniques such as Positron Emission Tomography might be a logical next step to determine the source of high postoperative serum CEA levels in some cases. The survival analysis indicated there is no significant difference between patients with known and unknown causes of high CEA levels, but patients whose CEA successfully returned to normal levels clearly demonstrated a better survival rate.

There are reports indicating that clinicopathological features, including gender, tumor depth, and lymph node metastasis, influence postoperative CEA levels. ${ }^{14,15}$ In contrast, other reports have demonstrated that gender is not a significant factor for CEA levels. In the present study, abnormal postoperative CEA levels were significantly more common in male patients. However, we could not conclude that gender predicted the persistence of high postoperative CEA because the number of patients analyzed was limited.

Pathological stage plays the most important role in the prognosis of CRC patients ${ }^{16}$. The committee of the College of American Pathologists Consensus Conference stated in 1999 that the TNM categories and stage subgroups have clinical value in prognosis. ${ }^{17}$ They also recommended assessing preoperative CEA levels for prognosis of the category I group. Among other suggested prognostic factors for category I, preoperative serum CEA was the only factor not included in the AJCC staging system. ${ }^{16}$ According to guidelines of the European Group on Tumor Markers, CEA is considered to possess independent prognostic value. ${ }^{18}$ The present study included a correlation between abnormal preand postoperative serum CEA levels with AJCC stages. As in other reports, advanced stage significantly correlated with higher pre - and postoperative CEA levels. We and many other investigators suggest that serum CEA levels should be added to the current staging system. ${ }^{7,15,19,20}$

In one study, the presence of lymph node metastasis correlated with CEA levels; ${ }^{2}$ however, this finding was not apparent in our study due to the presence of patients with lymph node metastases.

Carcinoembryonic antigen is widely used in the postoperative course of patients with CRC. ${ }^{22} \mathrm{~A}$ high concentration of postoperative serum CEA during followup predicts an adverse outcome. ${ }^{23}$ Early detection of CRC relapse is an important factor in reducing cancer mortality. ${ }^{24}$ The level of postoperative CEA has been shown to correlate with metastasis and local recurrence. ${ }^{25,26}$ Carcinoembryonic antigen has shown promise as an indicator of residual disease before recurrence becomes clinically apparent, and patients with recurrence might be cured if the residual disease were identified and treated effectively at an earlier time. Studies have reported that in $18-75 \%$ of cases with CRC relapse, there is a rise in postoperative CEA levels prior to clinically observable recurrence. ${ }^{25,27}$ This rise has been reported as early as 4 months prior to recurrence, ${ }^{28}$ should aware for the potential of recurrence and it is also possible to detect the relapse at an early stage. In the present study, 12 of 22 patients (54\%) with increased CEA values after surgery had metastases confined to the liver, lung, or locoregional areas that were detected within the first 2 years of diagnosis.

There are other factors that affect postoperative serum CEA concentrations in CRC patients. Serum CEA may be increased in epithelial tumors at other sites (both benign or malignant) in inflammatory bowel disease, pancreatitis, liver disease, pulmonary infection, in the presence of bowel obstruction, and in persons who smoke..$^{22}$ In the present study, patients with a known second neoplastic disease and with abnormal liver function were excluded from the study. However, there were patients with postoperative complications, such as pulmonary disorders (including pneumonia, pleural effusion, atelectasia), toxic hepatitis and abnormal renal functions due to anesthesia, and mechanical or paralytic bowel obstruction caused by surgery. These causes may be responsible for a postoperative increase in serum CEA in patients that did not demonstrate local recurrence or metastasis. We conclude that patients with high CEA concentrations after surgery should be thoroughly studied with the understanding that elevated CEA often, but not always, predicts the recurrence of CRC.

Goldstein et al. stated that a failure to return to normal CEA levels after surgery is indicative of systemic disease. ${ }^{29}$ 
Slentz et al. suggested that if initially elevated serum CEA levels remain high after surgery, they may be an indicator of increased risk $^{30}$. Our study demonstrated a better overall survival rate for groups 1 and 4 compared to the other groups. The present trial demonstrated that patients with high preoperative postoperative CEA levels exhibit poorer outcome. Moreover, the multivariate analysis indicated that abnormal postoperative serum CEA levels, lymph node metastases, and the primary tumor site are predictive factors for recurrence. Postoperative CEA was the most predictive factor for recurrence, with a relative risk of 4.050. Furthermore, the postoperative serum CEA level was the only predictive factor for survival. According to these findings, abnormal postoperative serum CEA levels, lymph node metastases, and the primary tumor site are independent prognostic factors for postoperative surveillance. In our opinion, CRC patients with abnormal postoperative serum CEA levels should be followed-up for extensive analysis and should, potentially, receive adjuvant chemotherapy.

\section{CONCLUSION}

Persistent high levels of postoperative serum CEA levels are a clinically important predictor of poor prognosis. The presence of such levels is an effective measurement of therapy after curative resection. Surveillance of patients with high postoperative serum CEA with an unknown cause should be extended, and these patients should be examined with sensitive diagnostic methods and should, potentially, be treated for recurrence at an earlier stage of disease.

\section{REFERENCES}

1. Wang WS, Lin JK, Chiou TJ, Liu JH, Fan FS, Yen CC, et al. Preoperative carcinoembryonic antigen level as an independent prognostic factor in colorectal cancer: Taiwan experience. Jpn J Clin Oncol. 2000;30:126

2. Wang JY, Lu CY, Chu KS, Ma CJ, Wu DC, Tsai HL, et al. Prognostic significance of pre- and postoperative serum carcinoembryonic antigen levels in patients with colorectal cancer. Eur Surg Res. 2007;39:245-50. Epub 2007; Apr 23.

3. Ma CJ, Hsieh JS, Wang WM, Su YC, Huang CJ, Huang TJ, et al. Multivariate analysis of prognostic determinants for colorectal cancer patients with high preoperative serum CEA levels: prognostic value of postoperative serum CEA levels. Kaohsiung J Med Sci. 2006;22:6049.

4. Carriquiry LA, Pineyro A. Should carcinoembryonic antigen be used in the management of patients with colorectal cancer? Dis Colon Rectum. 1999;42:921-9.

5. Duffy MJ. Carcinoembryonic antigen as a marker for colorectal cancer: is it clinically useful? Clin Chem. 2001;47:624-30.

6. Allende T, Garcia Muniz JL, Vizoso F, Del Casar JM, Raiqoso P, Llana B, et al. Preoperative serum levels of the carcinoembryonic antigen (CEA) and prognosis in colorectal cancer. Rev Esp Med Nucl. 2001;20:35864.

7. Wiratkapun S, Kraemer M, Seow-Choen F, Ho YH, Eu KW. High preoperative serum carcinoembryonic antigen predicts metastatic recurrence in potentially curative colonic cancer: results of a five-year study. Dis Colon Rectum. 2001;44:231-5.

8. International Union Against Cancer: TNM classification of malignant tumors, ed 6. New York, Wiley-Liss, 2002.

9. Sobin LH, Wittekind CH. TNM Classification of malignant tumours, 6th edition. Wiley-Liss, New York, 2002.

10. Friederichs J, Gertler R, Rosenberg R, Dahm M, Nekarda H, Holzmann $\mathrm{B}$, et al. Correlation of CK-20-positive cells in peripheral venous blood with serum CEA levels in patients with colorectal carcinoma. World J Surg. $2007 ; 31: 2329-34$.
11. Marchena J, Acosta MA, Garcia-Anguiano F, Simpson H, Cruz F. Use of the preoperative levels of CEA in patients with colorectal cancer. Hepatogastroenterology. 2003;50:1017-20.

12. Tsuchiya A, Ando Y, Kikuchi Y, Kanno M, Sato H, Yoshida T, et al. Reappraisal of preoperative carcinoembryonic antigen levels as a prognostic factor in resectable colorectal cancer. Fukushima J Med Sci. 1994;40:9-17.

13. McCall JL, Black RB, Rich CA, Harvey JR, Baker RA, Watts JM, et al The value of serum carcinoembryonic antigen in predicting recurrent disease following curative resection of colorectal cancer. Dis Colon Rectum. 1994;37:875-81.

14. Wiggers T, Arends JW, Volovics A. Regression analysis of prognostic factors in colorectal cancer after curative resections. Dis Colon Rectum. 1988:31:33-41

15. Ponz de Leon M, Sant M, Micheli A, Sacchetti C, Di Gregorio C, Fante $\mathrm{R}$, et al. Clinical and pathologic prognostic indicators in colorectal cancer. A population-based study. Cancer. 1992;69:626-35.

16. Chen CC, Yang SH, Lin JK, Lin TC, Chen WS, Jiang JK, et al. Is it reasonable to add preoperative serum level of CEA and CA19-9 to staging for colorectal cancer? J Surg Res. 2005;124:169-74.

17. Compton C, Fenoglio-Preiser CM, Pettigrew N, Fielding LP. American Joint Committee on Cancer Prognostic Factors Consensus Conference: Colorectal Working Group. Cancer. 2000;88:1739-57. Review

18. Duffy MJ, van Dalen A, Haglund C, Hansson L, Klapdor R, Lamerz $\mathrm{R}$, et al. Clinical utility of biochemical markers in colorectal cancer: European Group on Tumour Markers (EGTM) guidelines. Eur J Cancer. 2003;39:718-27.

19. Watine J, Miédougé M, Friedberg B. Carcinoembryonic antigen as an independent prognostic factor of recurrence and survival in patients resected for colorectal liver metastases: a systematic review. Dis Colon Rectum. 2001;44:1791-9.

20. Louhimo J, Carpelan-Holmström M, Alfthan H, Stenman UH, Järvinen HJ, Haglund C. Serum HCG beta, CA 72-4 and CEA are independent prognostic factors in colorectal cancer. Int J Cancer. 2002;101:545-8. 
Filiz AI et al.

21. American Society of Clinical Oncology. Clinical practice guidelines for the use of tumor markers in breast and colorectal cancer. J Clin Oncol. $1996 ; 14: 2843-77$

22. Rockall TA, Mc Donald PJ. Carcinoembryonic antigen: its value in the follow-up of patients with colorectal cancer. Int J Colorectal Dis. $1999 ; 14: 73-7$

23. Duffy MJ. Carcinoembryonic antigen as a marker for colorectal cancer: is it clinically useful? Clin Chem. 2001;47:624-30.

24. Wang JY, Lin SR, Wu DC, Lu CY, Yu FJ, Hsieh JS, et al. Multiple molecular markers as predictors of colorectal cancer in patients with normal perioperative serum carcinoembryonic antigen levels. Clin Cancer Res. 2007;13:2406-13.

25. Moertel CG, Fleming TR, MacDonald JS, Haller DG, Laurie JA, Tangen C. An evaluation of the carcinoembryonic antigen (CEA) test for monitoring patients with resected colon cancer. JAMA. 1993;270:943-
26. McCall JL, Black RB, Rich CA, Harvey JR, Baker RA, Watts JM, et al. The value of serum carcinoembryonic antigen in predicting recurrent disease following curative resection of colorectal cancer. Dis Colon Rectum. 1994;37:875-81.

27. Wedell J, Meier zu Esssen P, Luu TH, Fiedler R, van Calker H, Koldowski P, et al. A retrospective study of serial CEA determination in the early detection of recurrent colorectal cancer. Dis Colon Rectum. $1981 ; 24: 618-21$.

28. Northover J. Carcinoembryonic antigen and recurrent colorectal cancer. Gut. 1986;27:117-22.

29. Goldstein MJ, Mitchell EP. Carcinoembryonic antigen in the staging and follow-up of patients with colorectal cancer. Cancer Invest. 2005;23:33851 .

30. Slentz K, Senagore A, Hibbert J, Mazier WP, Talbott TM. Can preoperative and postoperative CEA predict survival after colon cancer resection? Am Surg. 1994;60(7):528-31; discussion 531-2. 